\title{
Phylogenetic analysis of members of the genus Rickettsia using the gene encoding the outer-membrane protein rOmpB (ompB)
}

\author{
V. Roux and D. Raoult
}

Unité des rickettsies, CNRS UPRES-A 6020, Faculté de Médecine, 27 Boulevard Jean Moulin, 13385 Marseille cedex 05, France
Author for correspondence: D. Raoult. Tel: +334913243 75. Fax: +334913877 72. e-mail: Didier.Raoult@medecine.univ-mrs.fr

To confirm the phylogenetic analysis previously inferred by comparison of the citrate synthase and rOmpA gene sequences (gltA and ompA, respectively), the rOmpB gene (ompB) of $\mathbf{2 4}$ strains of the genus Rickettsia was amplified and sequenced. rOmpB is an outer-membrane protein of high molecular mass, the presence of which can be demonstrated in most rickettsiae by immunological cross-reactivity in Western blots. No PCR amplification was obtained with Rickettsia bellii or Rickettsia canadensis. For the other rickettsiae, phylogenetic analysis was inferred from the comparison of both the gene and derived protein sequences by using parsimony, maximum-likelihood and neighbourjoining methods which gave the same organization. All nodes were well supported ( $>86 \%$ bootstrap values), except in the cluster including Rickettsia africae strain $\mathrm{S}$ and Rickettsia parkeri, and this analysis confirmed the previously established phylogeny obtained from combining results from glt $A$ and ompA. Based on phylogenetic data, the current classification of the genus Rickettsia is inappropriate, specifically its division into two groups, typhus and spotted fever. Integration of phenotypic, genotypic and phylogenetic data will contribute to the definition of a polyphasic taxonomy as has been done for other bacterial genera.

Keywords: phylogenetic analysis, outer-membrane protein $\mathrm{rOmpB}$, Rickettsia, taxonomy

\section{INTRODUCTION}

Rickettsia are obligate intracellular, Gram-negative bacteria, the vectors and reservoirs of which are mainly arthropods, although they may also infect vertebrate hosts. For many years the genus Rickettsia has been subdivided into three subgroups. The scrub typhus group included only one species, Rickettsia tsutsugamushi, which has recently been excluded from the genus Rickettsia on the basis of $16 \mathrm{~S}$ rRNA gene sequence studies and reclassified in a new genus, Orientia (Tamura et al., 1995). The typhus group (TG) included three species: Rickettsia typhi, Rickettsia prowazekii and Rickettsia canadensis, and the spotted fever group (SFG) contained the other rickettsiae (Weiss \& Moulder, 1984). Comparison of the se-

Abbreviations: SFG, spotted fever group; TG, typhus group.

The GenBank accession numbers for the ompB gene sequences of the Rickettsia strains used in this study are shown in Fig. 1. quences of the citrate synthase gene $($ glt $A)$ and $16 \mathrm{~S}$ rDNA demonstrated that $R$. canadensis should not be included in the TG or SFG (Roux \& Raoult, 1995; Roux et al., 1997; Stothard \& Fuerst, 1995). Currently, only $R$. typhi, the agent of murine typhus, and $R$. prowazekii, the agent of epidemic typhus, are included in the TG. Another species, 'Rickettsia felis' was first suspected to cluster with $R$. typhi and $R$. prowazekii on the basis of immunofluorescence assays which indicated the close affinity of ' $R$. felis' with members of the TG. Similarities between ' $R$. felis' and TG rickettsiae were also present in the growth patterns of the organisms in cell culture and in immunoblotting studies (Azad et al., 1992; Radulovic et al., 1995). Subsequently, the classification of ' $R$. felis' in the TG has been questioned based on results obtained from comparative studies of the sequences of $16 \mathrm{~S}$ rDNA and glt $A$ genes and the gene encoding the $17 \mathrm{kDa}$ protein (Schriefer et al., 1994; Higgins et al., 1996).

The heterogeneous SFG contains rickettsiae which are generally transmitted by ixodid ticks. Recently, bac- 
Table 1. Rickettsial strains studied

\begin{tabular}{|c|c|c|c|c|}
\hline Taxon & Strain & Source & Geographic origin & Human disease \\
\hline Rickettsia conorii & $\operatorname{Seven}^{\mathrm{T}}\left(\right.$ Malish $\left.^{\mathrm{T}}\right)$, ATCC VR-613 $3^{\mathrm{T}}$ & Unknown & South Africa & Mediterranean spotted fever \\
\hline $\begin{array}{l}\text { Rickettsia conorii (Indian tick } \\
\text { typhus rickettsia) }\end{array}$ & ATCC VR-597 & Rhipicephalus sanguineus & India & Mediterranean spotted fever \\
\hline Astrakhan fever rickettsia & A-167 & Rhipicephalus pumilio & $\begin{array}{l}\text { Astrakhan region (formerly } \\
\text { USSR) }\end{array}$ & Astrakhan fever \\
\hline Israeli tick typhus rickettsia & ISTT CDC1 & Human & Israel & Israeli spotted fever \\
\hline Rickettsia sibirica & $246^{\mathrm{T}}$, ATCC VR- $151^{\mathrm{T}}$ & Dermacentor nuttali & Former USSR & Siberian tick typhus \\
\hline 'Rickettsia mongolotimonae' & Marseille 1 & Human & France & Unnamed spotted fever \\
\hline Rickettsia parkeri & Maculatum 20 & Amblyomma maculatum & Mississippi, USA & \\
\hline Rickettsia africae & ESF-5 & Amblyomma variegatum & Shulu Province, Ethiopia & African tick bite fever \\
\hline Strain S & $\mathrm{S}^{\mathrm{T}}$ & Rhipicephalus sanguineus & Armenia (formerly USSR) & \\
\hline Rickettsia slovaca & $13-\mathrm{B}$ & Dermacentor marginatus & Slovakia & Unnamed spotted fever \\
\hline $\begin{array}{l}\text { Rickettsia honei (Thai tick typhus } \\
\text { rickettsia) }\end{array}$ & TT- $118^{\mathrm{T}}$, ATCC VR- $599^{\mathrm{T}}$ & Ixodes sp. or Rhipicephalus sp. & Thailand & Flinders Island spotted fever \\
\hline Rickettsia honei & $\mathrm{RB}$ & Human & Tasmania & Flinders Island spotted fever \\
\hline Rickettsia rickettsii & $\mathrm{R}^{\mathrm{T}}\left(\right.$ Bitterroot $\left.^{\mathrm{T}}\right)$, ATCC VR-891 ${ }^{\mathrm{T}}$ & Dermacentor andersoni & Montana, USA & Rocky Mountain spotted fever \\
\hline Rickettsia japonica & $\mathrm{YM}$ & Human & Japan & Oriental spotted fever \\
\hline Rickettsia massiliae & Mtu $1^{\mathrm{T}}$ & Rhipicephalus turanicus & France & \\
\hline Bar 29 & Bar $29^{\mathrm{T}}$ & Rhipicephalus sanguineus & Spain & \\
\hline Rickettsia rhipicephali & $3-7-6$ & Rhipicephalus sanguineus & Mississippi, USA & \\
\hline Rickettsia aeschlimannii & $\mathrm{MC}^{\mathrm{T}}{ }^{\mathrm{T}}$ & Hyaloma marginatum & Morocco & \\
\hline Rickettsia montanensis & $\mathrm{M} / 5-6$ & Microtus sp. & Montana, USA & \\
\hline Rickettsia australis & Phillips & Human & Australia & Queensland tick typhus \\
\hline Rickettsia akari & $\operatorname{MK}^{\mathrm{T}}\left(\operatorname{Kaplan}^{\mathrm{T}}\right)$, ATCC VR-148 & Human & New York, USA & Rickettsial pox \\
\hline Rickettsia helvetica & С9P9 & Ixodes ricinus & Switzerland & \\
\hline Rickettsia prowazekii & Breinl $^{\mathrm{T}}$, ATCC VR- $142^{\mathrm{T}}$ & Human & Poland & Epidemic typhus \\
\hline Rickettsia typhi & Wilmington $^{\mathrm{T}}$, ATCC VR- $144^{\mathrm{T}}$ & Human & North Carolina, USA & Murine typhus \\
\hline
\end{tabular}

teria transmitted by insects have been proposed to belong to this group. These include the $\mathrm{AB}$ bacterium (Werren et al., 1994) which has been found to cluster with $R$. canadensis (Roux \& Raoult, 1995; Roux et al., 1997). Also they include the pea aphid rickettsia (Chen et al., 1996) and the PTB bacterium which clusters with Rickettsia bellii (Davis et al., 1998). Currently, more than 20 serotypes of the rickettsiae are described in the SFG. The description of several new potential SFG rickettsiae each year has highlighted the necessity for reliable tools to infer phylogenetic analysis to enable bacteria to be classified within this group. Interest in the $\mathrm{rOmpB}$ protein resulted from its outer-membrane location and the presence of epitopes in this protein which are common to both SFG and TG rickettsiae as demonstrated by immunological cross-reactivity in Western blotting analyses and other serological investigations. The rOmpB gene (omp B) was first described in $R$. prowazekii and was found to be 4776 bp (Carl et al., 1990). The gene encoding the rOmpB protein of Rickettsia rickettsii was then sequenced (Gilmore et al., 1989, 1991). In $R$. prowazekii this crystalline layer protein represents $10-15 \%$ of the total protein mass (Ching et al., 1996) and it was identified as the immunodominant species of surface protein antigen for most of the rickettsiae. Moreover, mAbs directed against $\mathrm{rOmpB}$ passively protected mice against lethal challenge of rickettsiae (Anacker et al., 1987).

To confirm the phylogenetic analysis that we recently inferred by combining data obtained from the citrate synthase gene $(g l t A)$ and rOmpA gene (ompA) (Roux et al., 1997; Fournier et al., 1998), we describe in this report the DNA sequences of $\mathrm{omp} B$ of 24 representatives of the genus Rickettsia.

\section{METHODS}

Rickettsial strains. The strains used in this study are listed in Table 1.

Rickettsial cultivation. SFG and TG rickettsiae were grown on Vero cell monolayers as described previously (Roux et al., 1997). When the degree of infection was optimal, as estimated by Gimenez staining, rickettsiae were harvested and cultures were centrifuged at $12000 \mathrm{~g}$ for $10 \mathrm{~min}$, resuspended in medium and stored at $-70^{\circ} \mathrm{C}$ until nucleic acid purification was performed.

Nucleic acid purification and PCR amplification. Genomic DNA was extracted using Qiagen columns (QIAamp Tissue Kit), according to the manufacturer's instructions. PCR amplification reactions were performed using the oligonucleotide primers listed in Table 2. Most of the primers were designed following identification of suitable hybridization sites within conserved regions of the gene after alignment of the sequence of $R$. rickettsii (GenBank accession no. X16353) and $R$. prowazekii (M37647). Some of the primers were chosen specifically, after determination of a part of the sequence of the $о m p B$ gene, for Rickettsia akari, Rickettsia australis and Rickettsia helvetica. Each PCR was carried out in a Peltier model PTC-200 thermal cycler (MJ Research). Five microlitres of the DNA preparation was amplified in a $50 \mu \mathrm{l}$ reaction mixture containing $25 \mathrm{pmol}$ each primer, $200 \mu \mathrm{M}$ (each) dATP, dCTP, dGTP and dTTP (Gibco), 1 U Elongase (Gibco); $2 \mu \mathrm{l}$ buffer $\mathrm{A}$ and $8 \mu \mathrm{l}$ buffer B. The following conditions were used for amplification: initial denaturation for $3 \mathrm{~min}$ at $95^{\circ} \mathrm{C}$ was followed by 40 cycles of denaturation for $30 \mathrm{~s}$ at $95^{\circ} \mathrm{C}$, annealing for $30 \mathrm{~s}$ at $50{ }^{\circ} \mathrm{C}$ and extension for $1 \mathrm{~min} 30 \mathrm{~s}$ at $68^{\circ} \mathrm{C}$. The amplification was completed by holding the reaction mixture for $7 \mathrm{~min}$ at $68^{\circ} \mathrm{C}$ to allow complete extension of the PCR products. Primer pairs used for all the bacteria were 120M59 and 120-807, 120-607 and 120-1497, 120-1378 and 1202399, 120-2113 and 120-2988, 120-2788 and 120-3599, 1203462 and 120-4346, and 120-4232 and 120-4879. The seven 
Table 2. Oligonucleotide primers used for PCR amplification and sequencing of rickettsial species

\begin{tabular}{|c|c|c|c|c|}
\hline Fragment & Primer & Nucleotide sequence & $\begin{array}{l}\text { rOmpB gene } \\
\text { positions } \\
\text { relative } \\
\text { to the ORF }\end{array}$ & Organisms used \\
\hline I & $\begin{array}{l}120-\mathrm{M} 59 \\
120-807\end{array}$ & $\begin{array}{l}\text { CCGCAGGGTTGGTAACTGC } \\
\text { CCTTTTAGATTACCGCCTAA }\end{array}$ & $\begin{array}{c}\text { M59-M41 } \\
807-788\end{array}$ & $\begin{array}{l}\text { All } \\
\text { All except } R \text {. helvetica }\end{array}$ \\
\hline II & $\begin{array}{l}120-607 \\
120-1497\end{array}$ & $\begin{array}{l}\text { AATATCGGTGACGGTCAAGG } \\
\text { CCTATATCGCCGGTAATT }\end{array}$ & $\begin{array}{c}607-626 \\
1497-1480\end{array}$ & $\begin{array}{l}\text { All except } R \text {. helvetica } \\
\text { All except } R \text {. helvetica }\end{array}$ \\
\hline III & $\begin{array}{l}120-1378 \\
120-2399\end{array}$ & $\begin{array}{l}\text { TAAACTTGCTGACGGTACAG } \\
\text { CTTGTTTGTTTAATGTTACGGT }\end{array}$ & $\begin{array}{l}1378-1397 \\
2399-2378\end{array}$ & $\begin{array}{l}\text { All except } R \text {. helvetica } \\
\text { All except } R \text {. helvetica }\end{array}$ \\
\hline IV & $\begin{array}{l}120-2113 \\
\text { 120AA-2235 } \\
120-2988 \\
120 \mathrm{AA}-3042\end{array}$ & $\begin{array}{l}\text { CGATGCTAACGTAGGTTCTT } \\
\text { GGTACAGTTGGTACGCCTGC } \\
\text { CCGGCTATACCGCCTGTAGT }\end{array}$ & $\begin{array}{l}2113-2132 \\
2235-2254 \\
2988-2969\end{array}$ & $\begin{array}{l}\text { All except } R \text {. akari and } \\
R . \text { australis } \\
R . \text { akari, } R \text {. australis } \\
\text { All except } R \text {. akari and } \\
\text { R. australis } \\
\text { R. akari, } R \text {. australis }\end{array}$ \\
\hline V & $\begin{array}{l}120-2788 \\
120-3599\end{array}$ & $\begin{array}{l}\text { AAACAATAATCAAGGTACTGT } \\
\text { TACTTCCGGTTACAGCAAAGT }\end{array}$ & $\begin{array}{l}2788-2808 \\
3599-3579\end{array}$ & $\begin{array}{l}\text { All } \\
\text { All }\end{array}$ \\
\hline VI & $\begin{array}{l}120-3462 \\
120 \mathrm{AA}-3509 \\
120-4346\end{array}$ & $\begin{array}{l}\text { CCACAGGAACTACAACCATT } \\
\text { TACAGGAACTACAACCATTA } \\
\text { CGAAGAAGTAACGCTGACTT }\end{array}$ & $\begin{array}{l}3462-3481 \\
3509-3528 \\
4346-4327\end{array}$ & $\begin{array}{l}\text { All except } R \text {. akari and } \\
R . \text { australis } \\
R . \text { akari, } R \text {. australis } \\
\text { All }\end{array}$ \\
\hline VII & $\begin{array}{l}120-4232 \\
120-4879 \\
120-4489 * \\
120 \mathrm{H}-4108 \\
120 \mathrm{H}-4442 *\end{array}$ & $\begin{array}{l}\text { GGTTTCTCATTCTCTCTATATGG } \\
\text { TTAGAAGTTTACACGGACTTTT } \\
\text { GTCTTCTGACGAAAACTACAA } \\
\text { TCGGTGCTGCTGTCGGTATCA } \\
\text { GTCTTCTGACGAAAACTATAA }\end{array}$ & $\begin{array}{l}4232-4254 \\
4879-4857 \\
4489-4509 \\
4108-4127 \\
4442-4462\end{array}$ & $\begin{array}{l}\text { All except } R \text {. helvetica } \\
\text { All } \\
\text { All except } R \text {. helvetica } \\
R \text {. helvetica } \\
R \text {. helvetica }\end{array}$ \\
\hline $\begin{array}{l}\text { I, II, III } \\
R . \text { helvetica }\end{array}$ & $\begin{array}{l}120 \mathrm{H}-472^{*} \\
120 \mathrm{H}-558^{*} \\
120 \mathrm{H}-1010^{*} \\
120 \mathrm{H}-1192^{*} \\
120 \mathrm{H}-1627^{*} \\
120 \mathrm{H}-1746^{*} \\
120 \mathrm{H}-2203\end{array}$ & $\begin{array}{l}\text { CCTTTACTTGCAGCAGTACC } \\
\text { GGAAATGCACAGGCTACTTT } \\
\text { CGGTGCTGACGGTAATAGTT } \\
\text { GCACCGATATTACCGTTAAT } \\
\text { CCGATANGCAAGGTATAATTG } \\
\text { GACCAAGAGCCACATTTTGA } \\
\text { GCGTTACCTAAGAAGTAAGCC }\end{array}$ & $\begin{array}{c}472-453 \\
558-577 \\
1010-1029 \\
1192-1173 \\
1627-1647 \\
1746-1727 \\
2203-2183\end{array}$ & $\begin{array}{l}R . \text { helvetica } \\
R . \text { helvetica } \\
R . \text { helvetica } \\
R . \text { helvetica } \\
R . \text { helvetica } \\
R . \text { helvetica } \\
R . \text { helvetica }\end{array}$ \\
\hline
\end{tabular}

* Oligonucleotide primer used only for sequencing.

fragments were amplified for all the rickettsiae except $R$. akari, $R$. australis and $R$. helvetica. For $R$. akari and $R$. australis, a new pair of primers was chosen to amplify fragment IV: 120AA-2235 and 120AA-3042. To obtain amplification of fragment VI we used primers 120AA-3509 and 120-4346. For $R$. helvetica, it was possible to amplify fragments IV, V and VI. By determining the sequence of fragment VI and choosing a new primer, 120H-4108, which was used with primer $120-4879$, we were able to amplify the $3^{\prime}$ end of the gene of $R$. helvetica. We determined a part of the $3^{\prime}$ end sequence of fragment IV and chose a new primer, $120 \mathrm{H}-2203$, which, with 120-M59, enabled the amplification of a fragment of $2261 \mathrm{bp}$.

Sequencing reaction. PCR products were purified using a QIAquick Spin PCR Purification Kit (Qiagen) as described by the manufacturer. Sequencing reactions were carried out using a DNA sequencing kit (dRhodamine Terminator Cycle Sequencing Ready Reaction Fit with AmpliTaq Polymerase FS; Applied Biosystems) as described by the manufacturer. Sequence products were purified and resolved on $5 \%$ polyacrylamide gels (Long Ranger Singel packs, Type 377-36cm WTR; Tebu) and electrophoresis was performed with the ABI PRISM 377 DNA sequencer (Perkin Elmer). The same primers as those used for PCR amplification were used for the sequencing reactions. Primers $120 \mathrm{H}-4442$ and $120-4489$ were used to confirm the sequence of the $3^{\prime}$ end of the gene of $R$. helvetica and other rickettsiae. The primers $120 \mathrm{H}-472,120 \mathrm{H}-558,120 \mathrm{H}-1746$, $120 \mathrm{H}-1010,120 \mathrm{H}-1192$ and $120 \mathrm{H}-1627$ were chosen to obtain complete $R$. helvetica sequences of both DNA strands of the fragment amplified using the primer pair 120-M59 and $120 \mathrm{H}-2203$.

Data analysis. The $о m p B$ sequences were translated into protein sequences using PC/GENE software (IntelliGenetics). The $о m p B$ sequences and $\mathrm{rOmpB}$ amino acid sequences were aligned using the multisequence alignment program CLUSTAL within the BISANCE environment (Dessen et al., 1990). The percentage similarities were determined using the PC/GENE software package. The phylogenetic relationships between the studied representatives of the genus Rickettsia were 
determined using the PHYLIP software package version 3.4 (Felsenstein, 1989). Distance matrices generated by DNADIST and PROTDIST were determined under the assumptions of Kimura (1980). These matrices were used to elaborate dendrograms using the neighbour-joining method (Saitou \& Nei, 1987). The data were also examined by using parsimony and maximum-likelihood methods (DNAPARS, PROTPARS and DNAML in PHYLIP). A bootstrap analysis was performed to investigate the stability of the trees obtained. Bootstrap values were obtained for a consensus tree based on 100 randomly generated trees by using SEQBOOT and CONSENSE in the same package.

\section{RESULTS}

\section{PCR amplification and sequencing}

$o m p B$ fragments were amplified from all the studied strains of Rickettsia except $R$. bellii strain 369L42-1 and $R$. canadensis strain 2678.

The sequence of both DNA strands was determined twice. The $о m p B$ gene was sequenced between bases 1 and 5210 with respect to the $R$. rickettsii published sequence. Sequence similarity of $100 \%$ was obtained with the published sequences of $R$. rickettsii (Gilmore et al., 1989) and R. typhi (Hahn et al., 1993) but only $99.8 \%$ similarity was obtained with the sequence of $R$. prowazekii published by Carl et al. (1990). Different sequences were obtained for two strains of Rickettsia conorii (ATCC VR-597 and Seven ${ }^{\mathrm{T}}$ ) and two strains of Rickettsia honei (TT-118 ${ }^{\mathrm{T}}$ and RB). The percentage similarity between strains ATCC VR-597 and Seven ${ }^{\mathrm{T}}$ was $99.8 \%$ for the DNA sequence and $99.5 \%$ for the protein sequence. For the TT-118 ${ }^{\mathrm{T}}$ and RB strains the values were 99.9 and $99.8 \%$ for the DNA and protein sequences, respectively. Between two different species the highest percentage similarity was obtained for Rickettsia sibirica and 'Rickettsia mongolotimonae' (99.6\% DNA, 99.1\% protein). The lowest similarity was observed between $R$. typhi and $R$. helvetica $(70 \%$ DNA, $51 \cdot 7 \%$ protein).

\section{Phylogeny inference}

The dendrograms obtained with the three different tree-building analysis methods used showed similar organization for most of the rickettsiae, whether inferred from the gene or the derived protein sequences. The two representatives of the TG, $R$. prowazekii and $R$. typhi, clustered together. We identified four monophyletic groups within representatives of the SFG: $R$. akari and $R$. australis clustered together and $R$. helvetica was alone on a separate branch. Another group consisted of Rickettsia montanensis, Rickettsia aeschlimannii, Rickettsia rhipicephali, Rickettsia massiliae and Bar 29. The fourth group could be divided into three subgroups. One included $R$. honei and $R$. rickettsii; the second included Rickettsia africae, strain S, Rickettsia parkeri, $R$. sibirica and ' $R$. mongolotimonae'; and the third group consisted of the $R$. conorii complex ( $R$. conorii strains, Astrakhan fever rickettsia and Israeli tick typhus rickettsia). Rickettsia slovaca and Rickettsia japonica did not cluster with any Rickettsia species. All the nodes were well supported $(\geqslant 87 \%$ bootstrap values for dendrograms inferred from comparison of gene and derived protein sequences; Fig. 1) except in the subgroup including $R$. africae, strain $\mathrm{S}$ and $R$. parkeri (from 40 to $46 \%$ in the dendrogram inferred from ompB sequences; from 54 to $62 \%$ in the dendrogram inferred from derived protein sequences).

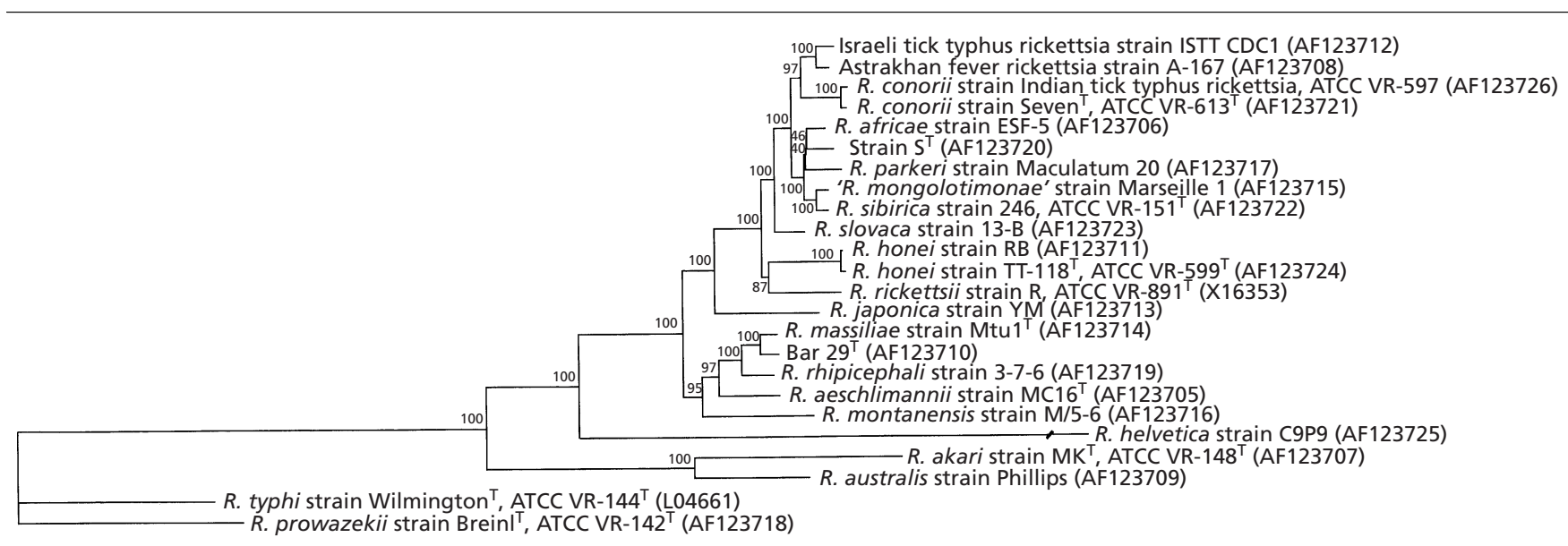

$2 \cdot 5 \%$ difference

Fig. 1. Dendrogram representing phylogenetic relationships between Rickettsia species inferred from comparison of omp $B$ gene sequences. The sequences were aligned using the multisequence alignment program CLUSTAL, which is a part of the BISANCE software package. Phylogenetic relationships were inferred with the PHYLIP software package version 3.4. The evolutionary distance values were determined by the method of Kimura and these values were used to construct a dendrogram by the neighbour-joining method. The numbers at nodes are the proportion of 100 bootstrap resamplings that support the topology shown. GenBank accession numbers for the sequences used are in parentheses. 


\section{DISCUSSION}

For strict intracellular bacteria such as rickettsiae, few phenotypic characters are expressed or can be readily studied and the taxonomy of these organisms is based mainly on genomic criteria. Recently, we have demonstrated that the phylogenetic analysis of rickettsiae is possible by comparing their DNA sequences. Reliable analysis of all the isolates of the genus Rickettsia, as confirmed by high bootstrap values, was only obtained, however, by combining the data derived from the comparison of almost complete sequences of glt $A$ and omp $A$ (except tandem repeats) (Roux et al., 1995; Fournier et al., 1998). Since the gltA gene encodes citrate synthase, a highly conserved enzyme essential in the central metabolic pathways of the rickettsiae, the sequences we obtained for this gene were only significantly different between organisms distantly related to each other. Also, omp $A$ is a gene encoding an outer-membrane protein specific to the SFG rickettsiae but not to all representatives of the genus Rickettsia. As it is important to compare the sequences of several genes to evaluate their use in establishing rickettsial phylogeny, as suggested by Olsen \& Woese (1993), and since we were also looking for a versatile DNA target available for all the rickettsiae, we considered $о m p B$ to be a good candidate for further study.

rOmpB is a crystalline $\mathrm{S}$-layer protein which has been characterized in nearly all phylogenetic lines (Sleytr \& Messner, 1983), although the majority of sequenced Slayer genes have been found to have little sequence identity (Bahl et al., 1997). S-layers have been shown to be involved in the rigidity and shape of bacteria, to function as molecular sieves and ion traps and to be promoters for cell adhesion and surface recognition (Sleytr \& Messner, 1988). In our experiments using PCR amplification with consensus primers established by comparison of published sequences of rickettsiae, we were able to determine the sequences of $о \mathrm{mp} B$ in all the rickettsiae we studied except for $R$. canadensis and $R$. bellii. This result is consistent with that obtained previously using glt $A$ and suggests that these two rickettsia, and also the $\mathrm{AB}$ bacterium, were the first to diverge from the common ancestor of this group (Roux et al., 1997). Methods such as 'genome walking' should be considered in future experiments to obtain the gene sequence of these rickettsiae as only one specific primer will be necessary (Siebert et al., 1995). The rapid rate of evolution we found for this gene in $R$. helvetica compared to that of the other representatives of the genus that we studied was surprising. Using PFGE, we have shown previously that the genome of $R$. helvetica $(1400 \mathrm{~kb})$ is longer than that of most of the other SFG rickettsiae $(1200-1300 \mathrm{~kb}$ ) (Roux \& Raoult, 1993). Further studies are needed to determine if, during its evolution, $R$. helvetica was exposed to particular selective forces imposed by factors affecting its arthropod or mammalian hosts. Nevertheless, we can consider that its phylogenetic position between the
R. massiliae subgroup and the cluster including $R$. akari and $R$. australis is established.

The phylogenetic position of $R$. rickettsii and $R$. honei, which grouped together, was well supported by analyses on $o m p B$, contrary to analysis on glt $A$ and $o m p A$. The other subgroups, however, were identical to those identified by Fournier et al. (1998) and high bootstrap values were calculated for all supporting nodes. The single remaining problem is the organization inside the cluster including $R$. parkeri, strain $\mathrm{S}$ and $R$. africae. Bootstrap values for the supporting nodes were not significant, even though the clusters were the same as those determined by ompA sequence comparison. Differences were noted in sequences of isolates of the same species; within the species $R$. conorii differences were found between the Indian tick typhus strain (ATCC VR-597) isolated from a Ripicephalus sanguineus tick and strain Seven ${ }^{T}$ isolated from a patient with Mediterranean spotted fever; within the species $R$. honei differences were found between TT$118^{\mathrm{T}}$ isolated from a tick in Thailand and the RB strain which is a human isolate from Flinders Island. These findings are the first to indicate differences between the above isolates as previously they were shown to be identical by analysis of their $g l t A$ and omp $A$ sequences. Gilmore et al. (1991) also described heterogeneity in the DNA sequence of virulent and avirulent strains of $R$. rickettsii. Further investigations are indicated to confirm the heterogeneity between different isolates of the same species and try to understand the significance of the finding.

According to modern biosystematics, including phylogeny and population genetics, it is evident that the present classification and nomenclature used for the genus Rickettsia are inadequate. The division of the genus into only the TG and SFG is not appropriate as $R$. canadensis and $R$. bellii have to be excluded from the TG and the SFG, respectively. The significance of the SFG has to be reconsidered as the rickettsiae included in this group in fact form well defined, distinct clusters of organisms.

Currently, phylogenetic studies have shown that several groups can be determined within the genus Rickettsia. In one group are most of the rickettsia, mainly the $R$. conorii complex ( $R$. conorii, Astrakhan fever rickettsia, Israeli tick typhus rickettsia), $R$. sibirica, ' $R$. mongolotimonae', $R$. africae, strain $\mathrm{S}$, $R$. parkeri, R. slovaca, $R$. rickettsii, $R$. honei and $R$. japonica. The second group includes $R$. massiliae, Bar 29, $R$. rhipicephali, $R$. aeschlimannii and $R$. montanensis. To date these bacteria have only been isolated from ticks and their pathogenicity in humans has yet to be determined. The third group includes $R$. typhi and $R$. prowazekii, the agents of endemic and epidemic typhus, respectively, and it appears appropriate then for this group to be named TG. The other groups are more difficult to define precisely. $R$. helvetica seems to have followed its own distinct evolutionary path. It has recently been recognized as a human pathogen (Nilsson et al., 1999). R. akari and R. 
Table 3. G + C content, DNA-DNA similarity and antibiotic susceptibility for different representatives of the genus Rickettsia

\begin{tabular}{|c|c|c|c|c|c|}
\hline Taxon & $\begin{array}{c}\mathbf{G}+\mathbf{C} \\
(\mathrm{mol} \%)^{*}\end{array}$ & $\begin{array}{c}\text { DNA-DNA } \\
\text { similarity/ } \\
\text { R. rickettsii }(\%)^{*}\end{array}$ & $\begin{array}{c}\text { DNA-DNA } \\
\text { similarity/ } \\
\text { R. prowazekii }(\%)^{*}\end{array}$ & $\begin{array}{l}\text { Erythromycin } \\
\text { susceptibility } \dagger\end{array}$ & $\begin{array}{c}\text { Rifampin } \\
\text { susceptibility } \dagger\end{array}$ \\
\hline \multicolumn{6}{|l|}{ R. rickettsii group: } \\
\hline R. conorii & $32-33$ & $91-94$ & NT & $\mathrm{R}$ & $\mathrm{S}$ \\
\hline R. rickettsii & $32-33$ & NT & 47 & $\mathrm{R}$ & $\mathrm{S}$ \\
\hline R. sibirica & $32-33$ & $70-74$ & NT & $\mathrm{R}$ & $\mathrm{S}$ \\
\hline \multicolumn{6}{|l|}{ R. massiliae group: } \\
\hline R. rhipicephali & $32-33$ & NT & NT & $\mathrm{R}$ & $\mathrm{R}$ \\
\hline R. montanensis & NT & 73 & NT & $\mathrm{R}$ & $\mathrm{R}$ \\
\hline R. massiliae & NT & NT & NT & $\mathrm{R}$ & $\mathrm{R}$ \\
\hline \multicolumn{6}{|l|}{ R. helvetica group: } \\
\hline$R$. helvetica & NT & NT & NT & $\mathrm{R}$ & $\mathrm{S}$ \\
\hline \multicolumn{6}{|l|}{ R. akari group: } \\
\hline R. akari & $32-33$ & 46 & NT & $\mathrm{R}$ & $\mathrm{S}$ \\
\hline R. australis & NT & 53 & NT & $\mathrm{R}$ & $\mathrm{S}$ \\
\hline \multicolumn{6}{|c|}{ R. prowazekii group: } \\
\hline R. prowazekii & $29-30$ & 47 & NT & $\mathrm{S}$ & $\mathrm{S}$ \\
\hline R. typhi & $29-30$ & 42 & 72 & $\mathrm{~S}$ & $\mathrm{~S}$ \\
\hline \multicolumn{6}{|c|}{ R. canadensis group: } \\
\hline R. canadensis & $29-30$ & 47 & 45 & $\mathrm{R}$ & $\mathrm{S}$ \\
\hline R. bellii & NT & NT & NT & $\mathrm{R}$ & $\mathrm{S}$ \\
\hline
\end{tabular}

* NT, Not tested.

$\dagger$ R, Resistant; S, sensitive.

australis are genetically closely related and should be included in their own group. ' $R$. felis', which is also genetically closely related, could be the third species in this group. More data are required to determine if $R$. bellii, $R$. canadensis and rickettsiae recently described in insects $(\mathrm{AB}$ bacterium, Pea aphid rickettsia, PTB bacterium) should be included in the same group.

Bacterial taxonomy should reflect the classification and nomenclature of the different representatives and allow the identification of unknown organisms (Vandamme et al., 1996). Expressed features such as morphology, physiology and ecology should also be reflected. Polyphasic taxonomy, which integrates data on numerous characteristics of organisms, seems to be the best approach for rickettsial taxonomy as has been shown to be the case with other bacterial genera (Vandamme et al., 1996). The different groups we have defined by phylogenetic analysis may serve as a basis to establish taxonomy and may be confirmed by other criteria such as natural antibiotic susceptibility (Rolain et al., 1998) which is usually supported by genetic specificity (Drancourt \& Raoult, 1999), G + C content and DNA-DNA hybridization, but few data are currently available (Walker, 1989; Table 3). For other bacterial genera it has been determined that different strains belong to the same species if they share $70 \%$ or greater DNA-DNA relatedness (Wayne et al., 1987). For rickettsiae, considering $70 \%$ as the threshold value, $R$. rickettsii, $R$. conorii, R. sibirica and $R$. montanensis would belong to the same species. So particular criteria would have to be determined for these bacteria as no rickettsiologist would accept this situation. A remaining problem is that rickettsiae are intracellular bacteria and, to date, the in vitro culture of some of the organisms has not been possible. The taxonomic position of these bacteria is now mainly based on gene sequence comparisons. Such phylogenetic analysis is only reliable, however, when it is based on sequences long enough to generate significant bootstrap values. Studies on limited gene sequence fragments could be useful for identifying bacteria, but not to reliably classify them. As primers are now available to amplify glt $A$, omp $A$ and $\operatorname{omp} B$, it will be judicious to establish the whole sequence of these genes to obtain a reliable phylogeny for all the bacteria identified as representatives of the genus Rickettsia.

Recently, the sequence of the entire genome of Rickettsia prowazekii was reported (Andersson et al., 1998) and we have undertaken the sequencing of the whole genome of $R$. conorii. Comparison of the two genomes will give a direct insight into the genetic basis and molecular characteristics of each of these bacteria. Such new information will greatly improve our understanding of the taxonomy of the genus Rickettsia.

\section{ACKNOWLEDGEMENTS}

We thank P. Kelly for review of the manuscript. 


\section{REFERENCES}

Anacker, R. L., McDonald, G. A., List, R. H. \& Mann, R. E. (1987). Neutralizing activity of monoclonal antibodies to heat-sensitive and heat-resistant epitopes of Rickettsia rickettsii surface proteins. Infect Immun 55, 825-827.

Andersson, S. G. E., Zomorodipour, A., Andersson, J. 0. \& 7 other authors (1998). The genome sequence of Rickettsia prowazekii and the origin of mitochondria. Nature 396, 133-140.

Azad, A. F., Sacci, J. B., Jr, Nelson, W. M., Dasch, G. A., Schmidtman, E. T. \& Carl, M. (1992). Genetic characterization and transovarial transmission of a typhus-like rickettsia found in cat fleas. Proc Natl Acad Sci USA 89, 43-46.

Bahl, H., Scholz, H., Bayan, N. \& 22 other authors (1997). Molecular biology of s-layers. FEMS Microbiol Rev 20, 47-98.

Carl, M., Dobson, M. E., Ching, W.-M. \& Dash, G. A. (1990). Characterization of the gene encoding the protective paracrystalline-surface-layer protein of Rickettsia prowazekii: presence of a truncated identical homolog in R. typhi. Proc Natl Acad Sci USA 87, 8237-8241.

Chen, D. Q., Campbell, B. C. \& Purcell, A. H. (1996). A new rickettsia from a herbivorous insect, the pea aphid Acyrthosiphon pisum (Harris). Curr Microbiol 33, 123-128.

Ching, W.-M., Wang, H., Jan, B. \& Dasch, G. A. (1996). Identification and characterization of epitopes on the 120-kilodalton surface protein antigen of Rickettsia prowazekii with synthetic peptides. Infect Immun 64, 1413-1419.

Davis, M. J., Ying, Z., Brunner, B. R., Pantoja, A. \& Ferwerda, A. P. (1998). Rickettsial relative associated with Papaya bunchy top disease. Curr Microbiol 36, 80-84.

Dessen, P., Fondrat, C., Valencien, C. \& Munier, G. (1990). BISANCE: a French service for access to biomolecular databases. CABIOS 6, 355-356.

Drancourt, M. \& Raoult, D. (1999). Characterization of mutations in the $r p o B$ gene in naturally rifampin-resistant Rickettsia species. Antimicrob Agents Chemother 43, 2400-2403.

Felsenstein, J. (1989). PHYLIP - phylogeny inference package (version 3.2). Cladistics 5, 164-166.

Fournier, P.-E., Roux, V. \& Raoult, D. (1998). Phylogenetic analysis of the spotted fever rickettsiae by study of the outer surface protein rOmpA. Int J Syst Bacteriol 48, 839-849.

Gilmore, R. D., Jr, Joste, N. \& McDonald, G. A. (1989). Cloning, expression and sequence analysis of the gene encoding the $120 \mathrm{kD}$ surface-exposed protein of Rickettsia rickettsii. Mol Microbiol 3, 1579-1586.

Gilmore, R. D., Jr, Cieplak, W., Jr, Policastro, P. F. \& Hackstadt, T. (1991). The 120 kilodalton outer membrane protein (rOmpB) of Rickettsia rickettsii is encoded by an unusually long open reading frame: evidence for protein processing from a large precursor. Mol Microbiol 5, 2361-2370.

Hahn, M.-J., Kim, K.-K., Kim, I. \& Chang, W.-H. (1993). Cloning and sequence analysis of the gene encoding the crystalline surface layer protein of Rickettsia typhi. Gene 133, 129-133.

Higgins, J. A., Radulovic, S., Schriefer, M. E. \& Azad, A. F. (1996). Rickettsia felis: a new species of pathogenic rickettsia isolated from cat fleas. J Clin Microbiol 34, 671-674.

Kimura, M. (1980). A simple method for estimating evolutionary rate of base substitutions through comparative studies of nucleotide sequences. J Mol Evol 16, 111-120.

Nilsson, K., Lindquist, O. \& Pahlson, C. (1999). Association of
Rickettsia helvetica with chronic perimyocarditis in Sudden. Lancet 354, 1169-1173.

Olsen, G. J. \& Woese, C. R. (1993). Ribosomal RNA: a key to phylogeny. FASEB J 7, 113-123.

Radulovic, S., Higgins, J. A., Jaworski, D. C., Dasch, G. A. \& Azad, A. F. (1995). Isolation, cultivation, and partial characterization of the ELB agent associated with cat fleas. Infect Immun $\mathbf{6 3}$, 4826-4829.

Rolain, J. M., Maurin, M., Vestris, G. \& Raoult, D. (1998). In vitro susceptibilities of 27 rickettsiae to 13 antimicrobials. Antimicrob Agents Chemother 42, 1537-1541.

Roux, V. \& Raoult, D. (1993). Genotypic identification and phylogenetic analysis of the spotted fever rickettsiae by pulsedfield gel electrophoresis. J Bacteriol 175, 4895-4904.

Roux, V. \& Raoult, D. (1995). Phylogenetic analysis of the genus Rickettsia by $16 \mathrm{~S}$ rDNA sequencing. Res Microbiol 146, 385-396.

Roux, V., Rydkina, E., Eremeeva, M. \& Raoult, D. (1997). Citrate synthase gene comparison, a new tool for phylogenetic analysis, and its application for the rickettsiae. Int J Syst Bacteriol 47, 252-261.

Saitou, N. \& Nei, M. (1987). The neighbor-joining method: a new method for reconstructing phylogenetic trees. Mol Biol Evol 4, 406-425.

Schriefer, M. E., Sacci, J. B., Jr, Dumler, J. S., Bullen, M. G. \& Azad, A. F. (1994). Identification of a novel rickettsial infection in a patient diagnosed with murine typhus. J Clin Microbiol 32, 949-954.

Siebert, P. D., Chenchik, A., Kellogg, D. E., Lukyanov, K. A. \& Lukyanov, S. A. (1995). An improved method for walking in uncloned genomic DNA. Nucleic Acids Res 23, 1087-1088.

Sleytr, U. B. \& Messner, P. (1983). Crystalline surface layers on bacteria. Annu Rev Microbiol 37, 311-339.

Sleytr, U. B. \& Messner, P. (1988). Crystalline surface layers in procaryotes. J Bacteriol 170, 2891-2897.

Stothard, D. R. \& Fuerst, P. A. (1995). Evolutionary analysis of the spotted fever and typhus groups of Rickettsia using $16 \mathrm{~S}$ rRNA gene sequences. Syst Appl Microbiol 18, 52-61.

Tamura, A., Ohashi, N., Urakami, H. \& Miyamura, S. (1995). Classification of Rickettsia tsutsugamushi in a new genus, Orientia gen. nov., as Orientia tsutsugamushi comb. nov. Int $J$ Syst Bacteriol 45, 589-591.

Vandamme, P., Pot, B., Gillis, M., De Vos, P., Kersters, K. \& Swings, J. (1996). Polyphasic taxonomy, a consensus approach to bacterial systematics. Microbiol Rev 407-438.

Walker, D. H. (1989). Rocky mountain spotted fever: a disease in need of microbiological concern. Clin Microbiol Rev 2, 227-240.

Wayne, L. G., Brenner, D. J., Colwell, R. R. \& 9 other authors (1987). International Committee on Systematic Bacteriology. Report of the ad hoc committee on reconciliation of approaches to bacterial systematics. Int J Syst Bacteriol 37, 463-464.

Weiss, E. \& Moulder, J. W. (1984). Order I. Rickettsiales Gieszczkiewicz 1939, 25 $5^{\mathrm{AL}}$, pp. 687-701. In Bergey's Manual of Systematic Bacteriology, vol. 1. Edited by N. R. Krieg \& J. G. Holt. Baltimore: Williams \& Wilkins.

Werren, J. H., Hurst, G. D., Zhang, W., Breeuwer, J. A. J., Stouthamer, R. \& Majerus, M. E. N. (1994). Rickettsial relative associated with male killing in the ladybird beetle (Adalia bipunctata). J Bacteriol 176, 388-394. 